Paulasto, H. \& S. Pöyhönen (toim.) 2020. Kieli ja taide - soveltavan kielentutkimuksen ja taiteen risteämiä. Language and the arts - creative inquiry in applied linguistics. AFinLA-e. Soveltavan kielitieteen tutkimuksia n:o 74. 192-217.

\title{
Sari Karjalainen
}

Helsingin yliopisto

\section{Keskustelua kuvassa? \\ Viiva ja väri vuorovaikutuksellisena toimintana}

This paper discusses visual art in the context of a project for aphatic people and their family members. The project was carried out to enhance the participants' capability for artistic expression and especially to enable them to experience visual art as a means of interaction in two different settings. In the first case, the interaction was realized through the artistic effort of individual participants working with visual material that functioned as a starting point for their work. In the second case, the artistic effort was shared interactively by two participants, primarily in a linguistically asymmetrical setting where one participant's linguistic competence was weakened due to a stroke followed by aphasia. The art works are discussed here from the artistic and philosophical points of view, revealing possible interactional elements and meanings. Moreover, based on the observed artistic inspiration and findings, the article discusses the possibilities and implications of visual art in aphasia therapy, focusing on some linguistic aspects and the nature of visual and pictorial elements. Finally, directions for further research are outlined for a better insight of the phenomenon of visual intersubjectivity in this special setting, thus opening new paths for research concerning visual art, linguistics, and aphasia.

Keywords: visual art, nonverbal, interaction, aphasia Asiasanat: kuvataide, ei-sanallinen, vuorovaikutus, afasia 


\section{Johdanto}

Afasiakuntoutuksessa työskennellään paitsi kielellisen myös kuvallisen materiaalin kanssa. Kuntoutuksista huolimatta monelle jää eriasteinen afasia, toisin sanoen kyvyttömyys puhua tai ymmärtää puhetta, lukea tai kirjoittaa. Aivohalvaukseen sairastumisesta seuraa usein pysyvä vammautuminen, jolla on mittavat vaikutukset henkilön arkitoimiin, ihmissuhteisiin ja vuorovaikutukseen ympäristön kanssa. Kielellisen ilmaisun puuttuessa afaattinen henkilö voi käyttää kommunikointiin kuvia yhdessä kehollisen olemuskielen rinnalla (esim. Von Tetzchner \& Martinsen 1999; Pulli ym. 2005).

Tässä artikkelissa käsittelen afaattisten henkilöiden ja heidän läheistensä kuvataidetta, joka syntyi kuvataideprojektissa Kadonnutta kättä etsimässä - Kuvallisia löytöretkiä sanojen syntysijoille. Tämä Itä-Savon AVH- ja afasiayhdistyksen kanssa toteutettu projekti oli lähtökohtaisesti taiteellinen. Sen tavoite oli afaattisten henkilöiden ja heidän läheistensä kuvataiteellinen työskentely ja siihen liittyi keskeisesti taiteen tekemisen saavutettavuuden mahdollistaminen. Projektilla ei ollut tutkimuksellisia tavoitteita, ellei sellaiseksi lasketa työpajoja ohjanneen taiteilijan tutkivaa työotetta, joka kohdistui kuvien toteutuksen vuorovaikutuksellisuuteen eri muodoissaan. Tämä toi projektiin taiteellisen tutkimuksen piirteitä. Työskentelyn keskeisenä ja kiinnostavana lähtökohtana oli osallistujien välinen kielellinen epäsymmetria. Kuvataiteella oli erityisesti yhteistyöskentelyssä vaihtoehtoisen, puhetta korvaavan ilmaisun rooli. Yhteisen kuvan äärellä afaattisen henkilön ja läheisen työskentely jäsentää heidän keskinäistä vuorovaikutustaan symmetriseen suuntaan, kun kielen ja puheen rooli ei ole osallistumisen ja vuorovaikutuksen onnistumisen kannalta tilanteessa ratkaiseva.

Tämän artikkelin tavoitteena on tuoda esiin afaattisten henkilöiden kuvataiteellisen työskentelyn mahdollisuuksia ja pohtia sen merkitystä erityisesti afasiaterapiassa, jossa sekä kuvallinen että kielellinen materiaali ovat keskeisiä. Terapiakuvamateriaalin ohella terapiassa käytetään perinteisesti apuna esimerkiksi piirtämistä, mutta muutoin afasiaterapiassa ei varsinaisesti ole sovellettu kuvataiteellista lähestymistapaa laajemmin. Tältä alueelta ei ole myöskään tehty tutkimusta. Taideterapiaa on toki käytetty neuropsykologisessa kuntoutuksessa sairastumiseen liittyvien tunteiden käsittelyssä. Toisaalta visuaalisuutta on hyödynnetty myös vuorovaikutuksen diagnostiikassa (Grätz 1978) ja esimerkiksi kuvallisiin symboleihin liittyen (Christensen 1982). Myös dementiaa sairastavien parissa taideterapiaa on käytetty (esim. Forssell 2008; Ranta 2011a; Sarajuuri 2008; Silvo 2008; Wadeson 2001). Tässä artikkelissa käsittelen kuvaesimerkkejä, jotka tuovat mielestäni esiin keskeisiä seikkoja paitsi kieleen ja vuorovaikutukseen liittyvien mahdollisten uusien terapiakäytänteiden kannalta ja jotka voisivat olla jatkossa tutkimuksen kohteena. 
Käsittelen tässä vain pientä osaa projektin kuvallisista tuotoksista. Näen projektin tuottamat kuvat kuvallisina keskusteluina, joissa vuorovaikutuselementti toteutuu eri tavoin. Koska tarkasteltavana on vain tekijöiden tuottamat kuvat ilman ajassa tapahtuvaa toimintaa, hain näkökulmia kuitenkin muualta kuin vuorovaikutus- tai keskusteluntutkimuksesta. Pyrin esimerkkien avulla avaamaan afasiatutkimuksen, kielentutkimuksen ja taiteentutkimuksen rajapintoja. Taiteentutkimuksen näkökulmasta pidän tässä keskeisenä tarkastelun ja pohdinnan kohteena kuvan aihetta ja kuvallisen työskentelyn motiivia. Esimerkkien yhteydessä nostan lyhyesti esiin mahdollisia lähestymistapoja, joista keskeinen on osallisuus (esim. Isola 2017). Kuvallista työskentelyä voidaan tarkastella osallisuuden näkökulmasta, joka saa tässä tukea taiteentutkimuksesta ja ruumiinfenomenologiasta. Mielestäni ei-kielellisen kommunikaation ja ruumiinkielen sekä näköaistin kohtaaminen taiteen alueella on kiinnostava ja liittyy keskeisesti tässä yhteydessä osallisuuteen. Osallisuuden näkökulma on ajankohtainen myös nykyisessä afasiaterapia-ajattelussa, joka on laaja-alaista ja osallisuutta korostavaa (Shrubsole ym. 2018). Osallisuuteen liittyen ammennan ajatuksia myös Bergerin fenomenologisesti suuntautuneesta tiedonsosiologiasta, joka tutkii todellisuuden sosiaalista rakentumista. Sosiaalinen todellisuus voi rakentua myös kuvallisen työskentelyn kautta (Berger 2003).

Taiteellisesta uteliaisuudesta toteutettu projekti synnytti ideoita ja pohdintoja liittyen kuvalliseen työskentelyyn afasiaterapiassa, jossa sekä kuva että kieli ovat keskeisiä elementtejä. Tässä yhteydessä heräsi pohdintoja myös kuvan ja sanan keskinäisistä eroista. Miten ne ovat yhteydessä toisiinsa? Pohtiessani afaattisen henkilön taidetyöskentelyä pyrin rajaamaan terapia-aspektien käsittelyn nimenomaan kognitiivisen ja erityisesti kielellis-kommunikatiivisen kuntoutuksen alueelle, vaikka eri alueiden rajapinta on epäilemättä häilyvä esimerkiksi psykiatrian alueelle painottuvan ekspressiivisen taideterapian kanssa (esim. Wilson 2001). Lisäksi taideprojekti synnytti ajatuksia tutkimuksesta. Työskentelyssä esiin nousseita ilmiöitä voitaisiin tarkastella jatkossa tieteellisellä otteella eri näkökulmista, joita hahmottelen lopuksi.

\section{Taide merkityksellisenä osana sosiaalista todellisuutta}

Osallisuus on kuulumista johonkin merkitykselliseen kokonaisuuteen (Isola 2017). Näin ollen se voi olla myös yhteiseen teokseen osallistumista. Kuvallisella työskentelyllä voidaan ylittää osallisuuden esteitä, joita afaattisilla henkilöillä ovat syrjäytyminen toisten yhteydestä, ymmärtämisen, sanoittamisen ja kuulumisen (eli viestin näkyville saamisen) vaikeus. Kuvallisen työskentelyn kautta osallistuja tulee nähdyksi ja hyväksytyksi. Yhteinen maalaustapahtuma on osallisuuden näkökulmasta hiljaista virittäytymistä toiseen. 
Berger (2003: 45) toteaa, ihmisen ilmaisukyky voi objektivoitua eli ilmentyä inhimillisen toiminnan tuotteina, jotka ovat sekä tuottajiensa että toisten ihmisten yhteisen maailman elementtejä. Tekijän käden jäljistä syntynyt kuva voi edustaa jotakin objektia ja olla siten sen merkki. Kaikkia objektivoitumia voidaan käyttää merkkeinä, vaikka niitä ei alun perin olisi tuotettu siihen tarkoitukseen. Eleet, tietyt ruumiinliikkeet ja materiaalisten tuotosten ryhmät ovat erilaisia merkkijärjestelmiä. Bergerin (2003: 47) mukaan esimerkiksi taiteen eri muodot ovat tällaisia merkkijärjestelmiä, jotka voivat olla osallistujien jakamaa todellisuutta.

Taidehistorioitsija Ville Lukkarinen (2015: 16) tuo esiin, miten piirustuspaperin pinnalla olevat merkit on nähty suorana seurauksena piirtäjän eleistä ja elehtimisestä paperin ääressä taidehistoriassa jo 1700-luvulla. Tuon myöhemmin esiin muita taiteen tutkimuksen ja taidehistorian tarjoamia näkökulmia, jotka sivuavat tässä käsiteltyjä kuvia. Useamman kuin yhden osallistujan yhteiselle paperille asettuvien maalausjälkien tarkastelu ja tulkinta on kiinnostavaa juuri osallisuuden näkökulmasta, kun eri tekijöiden siveltimien jäljet sulautuvat osaksi merkityksellistä kokonaisuutta, jota kautta ne voivat saada myös tulkintansa.

IImaisu on ruumiinliikkeiden välitöntä jatkoa myös abstraktissa ekspressionistisessa maalauksessa (esimerkiksi Jackson Pollock), jossa ilmaisun on sanottu koostuvan persoonallisista eleistä, jotka ovat verrattavissa hengittämiseen ja kädenjälkiin. Ekspressionismiin sisältyy välittömyyden idea, joka liittyy läsnäolon ja primitiivisyyden käsitteisiin. Ilmaisu on ruumiin liikkeiden läsnäoloa (Kuusamo 1990: 89-90). Ruumiinfenomenologiassaan MerleauPonty (2012) ajattelee ruumiin kautta sekä suhdetta itseen että toisiin. Hän tarkastelee ympäristön havainnointia kehollisena ja tilannesidonnaisena toimintana ja näkee piirtävien eleiden nousevan niiden kohteista. Kuvataidetta tarkastellessaan hän on todennut, että kuvataiteilija ilmaisee paperilla oman ruumiillisen maailmankohtaamisensa. Merleau-Pontyn ajattelussa on kiinnostavaa se, miten hänen teksteissään taideteoksen kohtaaminen rinnastuu usein toisen ihmisen kohtaamiseen.

Maalauksen tapahtuman motiivi voi olla tärkeämpi kuin näkyvä aihe. Lukkarinen (2005: 35) on käsitellyt piirtämistä paitsi ainutkertaisena kaksisuuntaisena kohtaamistilanteena myös aistimellisena paikkakokemuksena. Piirrettäessä syntyvät merkitykset voivat muodostua tärkeämmäksi kuin perinteinen sisällöllinen aihe. Ekspressionismissa maalausakti ei kuvaa sen takana olevaa alkuperäistä aihetta vaan on se aihe itsessään. Filosofi Elizabeth Groszin (2008: 59) mukaan maalausta ei tulisikaan ajatella esittävyytenä vaan aistittavan ja aistitun kanssa työskentelynä ja tämän aistitun maailman eteenpäin välittämisenä: "The work of art is a being of sensation and nothing else". Tämän aistitun maailman eteenpäin välittäminen on mahdollista ilman puhuttua kieltä. Edelleen Grosz (2008: 88) toteaa: “More generally, painting elevates colors and lines to the state of language". Maalatun kuvan elementtien 
rinnastaminen kieleen ei ole uusi asia, mutta tässä yhteydessä se nousee erityisen kiinnostavaksi näkökulmaksi.

Voimme tuoda esiin näiden yhteisesti maalattujen kuvien syntyprosessin erityisluonteen siis myös tietyn ryhmän erityisenä kohtaamisena. Kun teoksessa on eri tekijöiden tekemiä jälkiä, kukin maalaus on tuolloin dokumentti tietystä ainutkertaisesta tilanteesta, jossa tekijät ovat olleet vastavuoroisessa suhteessa toistensa kanssa. Tällöin yhteinen maalaus lähestyy paikkasidonnaista yhteisöllistä taideprosessia. Jos tarkastellaan tiettyjä maalauksia tekijöidensä näkökulmasta, paikan merkitys on ainutkertainen: yhteiset teokset eivät olisi syntyneet muussa kontekstissa.

Jokapäiväinen elämismaailma jäsentyy sekä ajallisesti että tilallisesti. Tilalla on sosiaalinen ulottuvuus sen seurauksena, että yksilön oma toimintakenttä käy ristiin toisten yksilöiden toimintakenttien kanssa (Berger 2003: 37). Näen afaattisten henkilöiden ja heidän läheistensä yhteiset maalaustilanteet tällaisina eri toimintakentistä rakentuvina tilanteina. Niissä on osallistujille ainutlaatuinen ja omanlaisensa atmosfääri, jossa syntyy aivan erityisiä kuvallisia muistiinpanoja osallistujien kohtaamisista. Kun yhteinen piirustus tai maalaus on suora ja välitön jälki tekijöidensä eleistä siinä hetkessä, jossa piirtäjä on kohdannut toisen piirtäjän, piirustuksen aiheeksi tulee samalla myös piirustustapahtuman hetki.

Ainutkertaisissa kuvallisissa kohtaamisissa tekijät siirtyvät taiteen avulla eri todellisuuteen ja rakentavat kuvan avulla yhteistä todellisuutta (Berger 2003). Taide tuottaa Bergerin (2003: 36) mukaan äärellisiä merkitysalueita, jossa vallitsevilla merkityksillä ja järjestyksellä voi olla runsaasti tai niukasti yhtymäkohtia jokapäiväisen elämän merkitysjärjestelmään. Kaikkia äärellisiä merkitysalueita luonnehtii tarkkaavuuden suuntautuminen poispäin jokapäiväisen elämän todellisuudesta. Taide on symbolisten ilmausten järjestelmä, joka edellyttää Bergerin (2003: 51) mukaan irrottautumista arkikokemuksesta, mutta jolla siitä huolimatta saattaa olla tärkeä merkitys jokapäiväisen elämän todellisuudelle. Symbolisesta taiteen kielestä voi tulla elämismaailman arkiymmärryksen olennainen rakenneosa.

Kun yksilön todellisuus muuttuu lähes täydellisesti sairastumisen seurauksena, hänen ja hänen läheisensä välinen vuorovaikutus muuttuu. Tämän vuorovaikutussuhteen uudelleen rakentamiseen erityisesti yhteinen kuvallinen työskentely voi tuoda uusia rakennusaineksia.

\section{Kuvataideprojekti: Tausta, tavoitteet ja toteutus}

Kuvataideprojektin taustalla on vuorovaikutuksen idean tutkiminen omassa taiteellisessa työskentelyssäni unpitsu-maalaustyöpajoissa saamieni kokemusten pohjalta. Opiskelin menetelmää japanilaisen kuvataiteilijan johdolla New Yorkissa vuosina 2006 ja 2007. 
Menetelmän tausta on kalligrafiassa, jossa kirjainmerkkien kurinalaisessa maalaamisessa siveltimenvedoilla on tarkka järjestys ja muoto. Unpitsu-maalauksessa pyritään irtautumaan siitä kohti mahdollisimman vapaata siveltimen liikettä, jota tekniikan nimikin tarkoittaa (jap. un pitsu, 'vapaa liike'). Siinä syntyvä maalaus on abstraktio. Sille on luonteenomaista spontaanius ja sattumanvaraisuus. Yllätyksen mahdollisuus liittyy paitsi syntyviin muotoihin, myös siveltimenjälkien kohtaamiseen. Tekijät voivat myös tietoisesti tai tahattomasti "koetella" toisiaan. Unpitsu -maalauksen ideaa seuraten tavoitteena oli leikkiä maalatuilla viivoilla.

Kuvataideprojektin keskeinen tavoite oli afaattisten henkilöiden ja heidän läheistensä kuvallisen ajattelun kehittäminen ja uudenlaisten kuvallisten kokemusten välittäminen osallistujien oman taiteellisen työskentelyn kautta. Siinä täytyi ylittää kuvallista ilmaisua rajoittavia asenteellisia kynnyksiä, jotka liittyvät ennakkoluuloihin ja käsityksiin siitä, että kuvan pitäisi esittää jotakin ja olla mahdollisimman näköinen. Oikean puolen halvaantumisen jälkeen myös "väärällä" kädellä tekemisen kynnys voi olla korkealla. Muutoinkin käsitys omasta itsestä voi heijastua uskona, ettei osaa piirtää tai maalata eikä varsinkaan tehdä taidokkaita kuvia. Toisaalta pyrkimys vapaaseen ja huolettomaan "lapsenomaiseen" ilmaisuun on haastavaa, koska kokemus omasta osaamisesta voi vertautua lapsen tasolle.

Tavoitteena oli rohkaista osallistujia tekemään kuvia, joissa irtaudutaan ennalta määritellyistä tai esittävistä kuvallisista merkityksistä. Abstraktin kuvan tekeminen oli osallistujille vierasta. Abstraktilla (tai ei-esittävällä, nonfiguratiivisella tai non-objektiivisella) taiteella tarkoitetaan taidetta, joka ei pyri esittämään mitään luonnollisen maailman kohteita, vaan maalaus voi koostua esimerkiksi pelkistä muodoista ja väreistä. Erityisenä tavoitteena oli luoda tilanteita, joissa afaattiset osallistujat pääsevät vuorovaikutukseen toistensa ja läheistensä kanssa kuvallisen työskentelyn kautta. Erityisesti afaattisen henkilön ja läheisen vuorovaikutuksen ja osallistumisen epäsymmetriaa pyrittiin tasoittamaan erilaisin kuvallisin keinoin.

Kuvataideprojektin osallistujat olivat aivohalvaukseen sairastuneita, eriasteisesta afasiasta kuntoutuvia henkilöitä sekä heidän läheisiään. Läheinen oli joko afaattisen henkilön puoliso tai henkilökohtainen avustaja. Kukaan osallistujista ei ollut aikaisemmin harrastanut kuvataidetta. Osallistujia oli kerrallaan 6-8. Toimin hankkeessa ohjaavana taiteilijana. Projekti sisälsi yhteensä 8 työpajapäivää, jotka toteutettiin noin joka toinen kuukausi. Yhden kerran aikana oli noin 4 tuntia työskentelyä. Ryhmäläiset olivat joka kerralla samoja henkilöitä.

Kuvan tekemisen teknisinä menetelminä olivat kollaasityöskentely, piirtäminen ja maalaaminen. Välineinä olivat vesiliukoiset maalit, tussi, hiili ja lyijykynä. Kuva oli työstämisen kohteena eri tavoin. Aluksi tutustuttiin kuvan rakentamisen perusteisiin kuten sommitteluun ja rajaamiseen. Osallistujat kokeilivat ja tutkivat erilaisia kuvallisia elementtejä - viivaa, 
värejä ja muotoja ja sitä, millaisista elementeistä esittävä ja ei-esittävä kuva voi rakentua. Työskentely toteutettiin paitsi yksin myös pareittain ja ryhmässä. Käytimme työskentelyssä myös ns. alkukuvia. Alkukuvatyöskentely on kehittämäni työmuoto, jossa tekijä saa työskentelynsä lähtökohdaksi erillisen kuvan, jonka varassa hän voi kehitellä omaa kuvallista aihetta. Kuvassa myös eri tekniikat voivat olla vuorovaikutuksessa keskenään.

\section{Projektin kuvia: Alkukuvan ja yhteisen paperin äärellä}

Työpajat jättivät jälkeensä runsaasti kuvallista materiaalia. Tässä artikkelissa esittelen viisi erilaista kuvaesimerkkiä. Tuon ne esiin abstrakteina maalauksina ja piirroksina, joissa vuorovaikutuselementti voi toteutua hieman eri tavoin. Poimin niistä esiin joitakin seikkoja kuvan aiheeseen ja elementteihin liittyen. Kaikissa esimerkeissä osallistujina on sekä afaattisia henkilöitä että läheisiä. En erittele yksittäisten kuvien kohdalla tarkemmin tekijöitä. Esimerkeissä 4.1 ja 4.2 on kuvia, joissa tekijä on työskennellyt yksin alkukuvan kanssa. Esimerkeissä 4.3 ja 4.4 on kahden tai useamman tekijän yhdessä tekemiä kuvia.

\subsection{Kuusi pientä maalausta}

Ajatus keskeneräisyydestä on keskeinen osa teosta ja alku vuorovaikutukselle. Keskeneräisyyden ideaa käsiteltiin jo 1700-luvulla kuvataiteen piirissä ja sitä pidettiin kiehtovana, koska kuvan keskeneräisyys voi stimuloida mielikuvitusta (Lukkarinen 2015: 21). Keskeneräisen kuvan voi mieltää fragmentiksi, jonka katsoja tai toinen tekijä, voi täydentää. Prosessuaalinen taideteos voi tuntua keskeneräiseltä ja luonnosmaiselta, mutta se voi silti olla eheä kokonaisuus. Kun tekijät saavat lähtökohdaksi omalle työskentelylleen jonkin kuvallisen elementin, kiinnostavaa on, miten eri tavoin tekijät osoittavat jatkavansa tai täydentävänsä tätä keskeneräistä alkukuvaa. Alkukuvan työstämiseen sisältyy implisiittinen odotus vuorovaikutuksesta toisen tekijän kuvan kanssa. Se luo teokselle pohjan. Alkukuvan täydentäminen synnyttää uusia kuvallisia aiheita. Näissä esimerkeissä (4.1 ja 4.2) tekijällä on mahdollisuus osallistua alkukuvan kuvamaailmaan lisäämällä siihen kuvallisia elementtejä. Niitä voitaisiin myös poistaa maalaamalla päälle kuvapohjan värillä; projektissa teimme myös näin.

Tekijät saivat työstettäväkseen sanomalehtipaperilla olevan kuvan (kuva 1). Alkukuvassa on vihreän ja valkoisen eriasteisista väri- ja valöörieroja. Tekijät saivat ohjeen viimeistellä tämä niin sanottu "keskeneräinen" kuva haluamallaan tavalla. Tekijöitä ei ohjattu työskentelyn aikana nimeämällä alkukuvaa tai muutoin antamalla vihjeitä siihen liittyen. Nostan kuvaesimerkeistä esiin joitakin kuvan elementtien väliseen vuorovaikutukseen liittyviä aspekteja, jotka liittyvät kuvallisen aiheen kehittelyyn. 


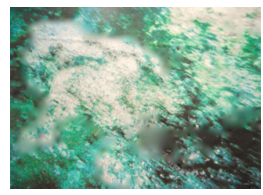

Kuva 1. Alkukuva kuvaesimerkkeihin 1-6

Alkukuva on abstrakti kuva, jossa on enemmän tai vähemmän erottuvia muotojen aihioita, jotka syntyvät väri- ja valöörieroista. Tekijät ottavat ne eri tavalla huomioon. Vuorovaikutus tekijän ja kuvamateriaalin välillä syntyy oman maalatun jäljen ja alkukuvan eri värisävyjen ja valöörien erilaisista kohtaamisista.

1

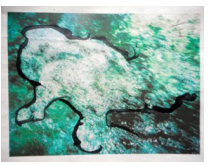

2

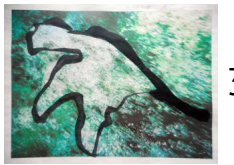

3

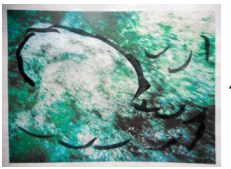

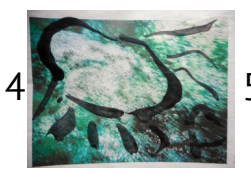

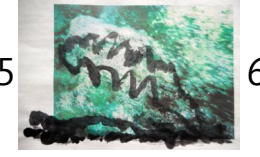

6

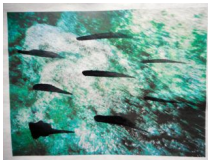

Kuva 2. Kuusi pientä maalausta. Tekniikka: tussi sanomalehtipaperille.

Kuvassa 2 on kuuden eri tekijän maalaukset. Niistä on nähtävissä, kuinka jokainen tekijä lähestyy alkukuvaa omalla persoonallisella tavallaan mustalla tussivärillä. Viittaan seuraavassa analyysitekstissä kuvassa 2 olevien kuvien numeroihin.

Kuvien 1-4 tekijät tukeutuvat selkeimmin erottuvia muotoihin. Tämän lisäksi kuvissa 3 ja 4 kehitellään siihen pohjautuvaa omaa aihetta. Kuvien 5 ja 6 tekijät luovat omia itsenäisempiä muotoja. Kuvan 5 tekijä hyödyntää selkeimmin erottuvaa vaaleaa aluetta oman kuvallisen aiheen kehittelyssä. Hän tukeutuu alkukuvan elementtiin eri tavalla kuin kuvien 1 - 4 tekijät. Kiinnostavaa on myös se, että kuvassa 5 tekijä ei rajaudu kuvapohjaan vaan kuva jatkuu sen yli. Selkeimmin alkukuva hahmottuu taustaksi omalle kuvalliselle aiheelle kuvassa 6.

Potentiaalisia kuvallisia aiheita sisältävä alkukuva ohjaa tekijöitä eri suuntaan. Jokainen tekijä nostaa esiin oman kuvallisen aiheen tutkiessaan alkukuvaa. Voidaan myös ajatella tekijän kommentoivan alkukuvan tarjoamia aiheita, käyvän keskustelua alkukuvan kanssa.

\subsection{Alkukuvan ja maalauksen sommitelmat}

Toisessa esimerkissä tarkastelen kuvia, joissa tekijä luo sommitelman alkukuvasta ja omasta maalauksesta. Alkukuva on musta suorakaide, jossa on valkoinen ovaalimuoto. Kuten edellä, jokainen työskentelee omalla paperillaan. 


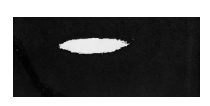

Kuva 3. Alkukuva esimerkkeihin 1-6

Tekijät osallistuvat alkukuvan tarjoamiin mahdollisuuksiin kukin omalla tavallaan, kun he jatkavat sitä maalaten. Paperikuvan ja tekijän omien maalausjälkien vuorovaikutuksesta, välillä syntyy erilaisia kuvallisia aiheita.
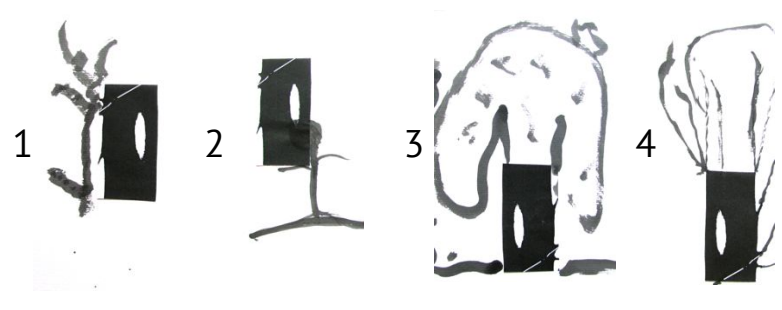

5

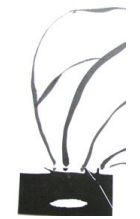

6

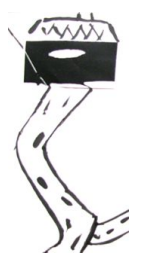

Kuva 4. Alkukuvan ja maalauksen sommitelmat. Sekatekniikka: Paperikuva ja tussi paperille.

Kuvassa 4 on kuuden tekijän sommitelmat. Jokainen sijoittaa alkukuvan eri tavoin ja eri kohtaan kuvapinnalla ja tekee erilaisen maalauksen suhteessa alkukuvaan. Eri tekijöiden töissä on sekä yhtäläisyyksiä että eroja aiheen ja tilan käsittelyssä.

Kuvissa 1-4 tekijä on asettanut alkukuvan pystysuoraan. Sijoittelultaan kuvat eroavat siten, että kuvissa 1 ja 2 alkukuva on sijoitettu paperin keskiosaan ja kuvissa 3 ja 4 paperin alaosaan. Alkukuva on myös asetettu eri tavalla kuvissa 1 ja 2 sekä 3 ja 4. Edellisissä mustassa suorakaiteessa oleva valkoinen ovaalimuoto on oikeassa reunassa ja jälkimmäisissä vasemmassa reunassa. Kuvissa 5 ja 6 alkukuva on asetettu vaakasuoraan. Kuvissa 3-5 on aihetta kehitelty samansuuntaisesti. Kuva kolme eroaa kuitenkin maalatun muodon suhteen kuvista 4 ja 5 . Kuva 5 on aiheen kehittelyltään saman tyyppinen kuin kuva 4.

Kuvissa yksittäisten elementtien ja niiden välisten yhteyksien esittävät merkitykset eivät ole ilmeisiä, vaikka kuvissa on tulkittavissa myös erilaisia orientaatioita esittävyyteen. Kuvassa 6 tekijä on täydentänyt alkukuvaa siten, että se hahmottuu rakennukseksi ja voisi ajatella, että siihen johtaa maalattu tie. Kuvallisesta kompositiosta löytyvä esittävyys on kuitenkin tulkinta, enkä tässä yhteydessä ota kantaa kuvien esittävyyteen.

Työskentelystä alkukuvan kanssa syntyy erilaisia kuvallisia esityksiä, kun tekijät tekevät samoista aineksista erilaisia kuvallisia ratkaisuja. Jokainen tekijä nostaa esiin alkukuvan 
uudessa kontekstissa, kun kehittelee kuvallista aihetta sekä valmiin että itse keksittyjen visuaalisten elementtien varassa.

Edellä olevissa esimerkeissä on kiinnostavaa miten eri tavoin alkukuvan voi ottaa lähtökohdaksi omalle kuvalliselle aiheelle. Aiheen käsittelyn kannalta oleellista on se, mikä aspekti alkukuvasta milloinkin nousee esiin. Pohdin tuonnempana tällaisen työmuodon mahdollisuuksia afasiaterapiassa.

\subsection{Kaksi väriä yhteisellä paperilla}

Tarkastelen seuraavaksi maalauksia, joissa kaksi tekijää on työskennellyt vuorotellen yhteisen paperin äärellä. Siveltimen jälkien lisäksi en pääse tässä tarkastelemaan, millaisia tekijöiden välisiä toiminnallisia vuorovaikutuksen ilmiöitä ja tekijöiden orientaatioita näihin maalauksiin kätkeytyy. Kahden eri tekijän siveltimenjälkien kohtaaminen voi olla täysin sattumanvaraista. Toisaalta toinen tekijä voi myös jatkaa toisen tekemää tai ottaa sen muutoin lähtökohdaksi omalle maalauseleelleen. Katson maalauksia taiteentutkimuksen tarjoamista näkökulmista käsin. Tässä erityisesti Groszia (2008) seuraten nostan maalaustapahtuman motiivin tärkeämmäksi kuin näkyvän aiheen. Poimin esimerkeistä (kuvat 5, 6 ja 7) esiin joitakin yksityiskohtia ja visuaalisia seikkoja, jotka liittyvät kuvan tilalliseen rakenteeseen ja kuvan elementtien organisoitumiseen. Niissä ilmenee yhteisen maalauspinnan sosiaalinen ulottuvuus, josta Berger (2003: 37) puhuu. Yksilön toimintakenttä käy ristiin toisten yksilöiden toimintakenttien kanssa.

Kun teoksessa on eri tekijöiden tekemiä jälkiä, kukin maalaus on tuolloin jälki tietystä ainutkertaisesta tilanteesta, jossa tekijät ovat olleet vastavuoroisessa suhteessa toistensa kanssa. Tällaisen yhteisesti tuotetun kuvan kaksiulotteisella pinnalla syntyvät merkitykset voivat muodostua tärkeämmäksi kuin perinteinen sisällöllinen aihe (Lukkarinen 2015). Kuvissa liikutaan eleiden ja kosketuksen aistienvaraisella maaperällä. Maalausta ei tulisikaan ajatella esittävyytenä vaan aistittavan ja aistitun kanssa työskentelynä ja tämän aistitun maailman eteenpäin välittämisenä (Grosz 2008: 59).

Kuvassa 5 on neljä maalausta, joissa jokaisessa on kaksi tekijää (afaattinen henkilö ja läheinen). Toinen heistä maalaa sinisellä ja toinen keltaisella.

1

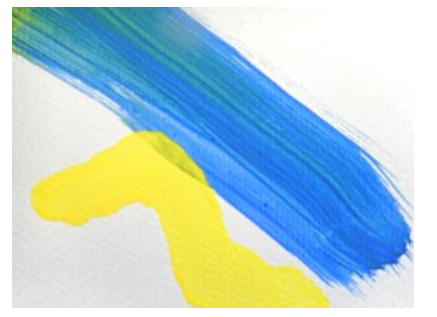

2

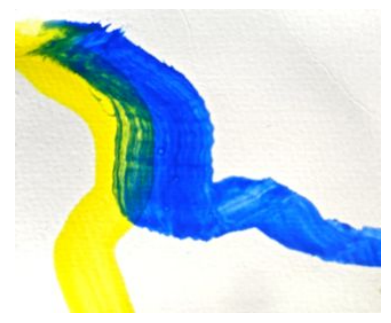



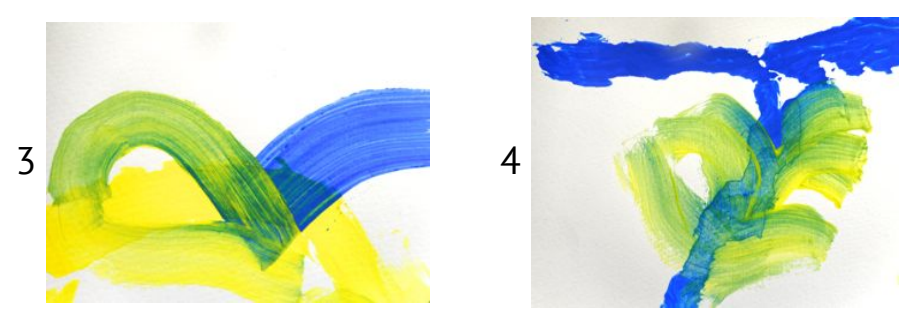

Kuva 5. Neljä maalausta sinisellä ja keltaisella. Tekniikka: akryyliväri paperille. Jokaisessa kuvassa kaksi tekijää (afaattinen henkilö ja läheinen).

Jos kuva muodostuu pelkästään eri värisistä viivoista, kiinnostus kohdistuu viivojen elämään ja dynamiikkaan. Kiinnostavaa on, onko kuvassa nähtävissä aihioita, tai merkkejä, viivojen välillä vallitsevasta vuorovaikutuksesta. Huomion kohteeksi nousee erityisesti siveltimenjälkien kohtaaminen sekä värien sekoittuminen. Aiemmin esitetyn Groszin (2008) näkemyksen pohjalta voidaan tämä kohtaaminen pukea sanoiksi niin, että maalausjäljet sananmukaisesti koskettavat toisiaan.

Kuvissa 1 ja 2 maalausjäljet kohtaavat ja kulkevat hetken samaa matkaa. Kuitenkin niin, että kuvassa 1 kohtaamisen hetki on lyhyempi. Kiinnostavaa on myös kerroksellisuus: keltainen asettuu sinisen päälle. Kuvassa 2 maalausjäljet ovat kiinteämmässä yhteydessä toisiinsa: Jälkien kulkema yhteinen matka on pidempi ja jäljet myös seurailevat toistensa muotoa. Kuvissa 1 ja 2 värit säilyvät itsenäisinä. Ainoastaan kuvassa 2 niiden kohtaamisessa värit sekoittuvat hieman vihreäksi.

Kuvissa 3 ja 4 värien sekoittuminen on ilmeistä. Niissä myös siveltimien jäljet ovat työstetympiä kuin kuvissa 1 ja 2. Lisäksi tekijöiden sivellintyöskentely vaikuttaa selvemmin kohdistetulta suhteessa toisen tekijän siveltimenjälkiin. Kuvassa 4 sekoittuneiden värien kautta tulee vaikutelma myös yhteisen muodon rakentamisesta, jossa värit asettuvat rauhallisesti yhteiseen muotoon.

Maalauksissa värien polut yhtyvät ja sekoittuvat keskenään, jolloin maalauksesta tulee paitsi voiman ja liikkeen, myös yhteisesti eletyn tilan kokemuksellinen esitys. Grosz on käsitellyt aboriginaalien aavikkomaalauksia, joissa voi lukea arkitodellisuudessa käveltyjä reittejä eli niissä on vastaavuus kuljetun maaston kanssa (Grosz 2008: 90). Tulkitsen tässä sinisestä ja keltaisesta rakentuvat maalaukset ei niinkään aiemmin kuljettuina reitteinä, vaan uusien reittien hahmotteluna, jossa kahden eri siveltimen jäljet kohtaavat fyysisessä vuorovaikutuksellisessa tilassa. Ne rakentavat taiteen avulla yhteistä sosiaalista todellisuutta (Berger 2003). Se rakentuu symmetrisesti, kun kielen ja puheen rooli ei ole tilanteessa ratkaiseva vuorovaikutuksen onnistumisen kannalta. 


\subsection{Hiilijälkiä ja muita merkkejä yhteisellä paperilla}

Vuorovaikutuksellinen tila ja Bergerin ajatus yhteisestä toimintakentästä tulee erityisen eksplisiittisesti esiin Hiilijälkiä -piirroksessa, jossa on kaksi tekijää (kuva 6).

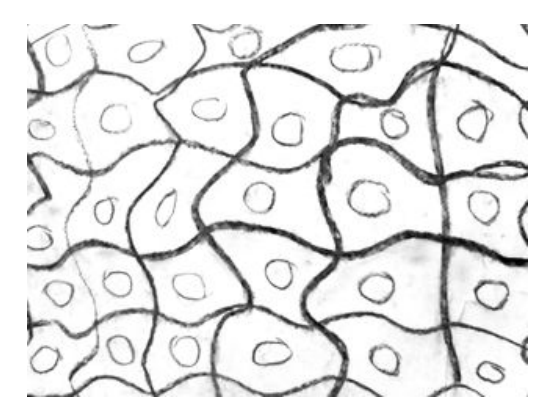

Kuva 6. Hiilijälkiä. Tekniikka: hiili paperille. Kaksi tekijää.

Hiilijälkiä -piirros on kiinnostava erityisesti yhteisen tilan näkökulmasta. Tekijöiden välinen vuorovaikutus toteutuu kahden erilaisen kuvallisen elementin (viivan ja pallomuodon) kautta. Kuvion jokaisella ruudulla on analoginen suhde toisiinsa, mutta ruudukon muodostavassa viivassa on variaatioita. Pallo sijoittuu kuitenkin aina viivoista muodostuvan tilan keskialueelle. Vuorottaisesta hiilijälkien toistosta syntyy abstrakti pintakuvio.

Piirros ilmentää hyvin, miten kuvan tilallinen rakenne on syntynyt kahden tekijän yhteistyönä. Tekijät ovat molemmat afaattisia henkilöitä. He ovat löytäneet yhteisen muotokielen ja tavoitteen. Kuvan syntyprosessin tuntevana, voisin nimetä sen myös esimerkiksi näin: Viivojen ja pallojen vuorovaikutusta. Tai pikemminkin näin: Vuorovaikutusta viivojen ja pallojen muodossa. Kyseinen piirros havainnollistaa eksplisiittisesti vuorovaikutteista kuvan rakentamisen prosessia, jossa tekijöille muodostunut omat roolit: toinen tekee ympyrän, toinen viivan. Viivoilla on oma rytminsä, mutta peruskuvio ja minimalistinen muotokieli säilyvät aina paperin täyttymiseen asti.

Kuvassa 7 on neljän osallistujan yhdessä tekemä maalaus. Siihen osallistui kaksi afaattista henkilöä ja kaksi läheistä. 


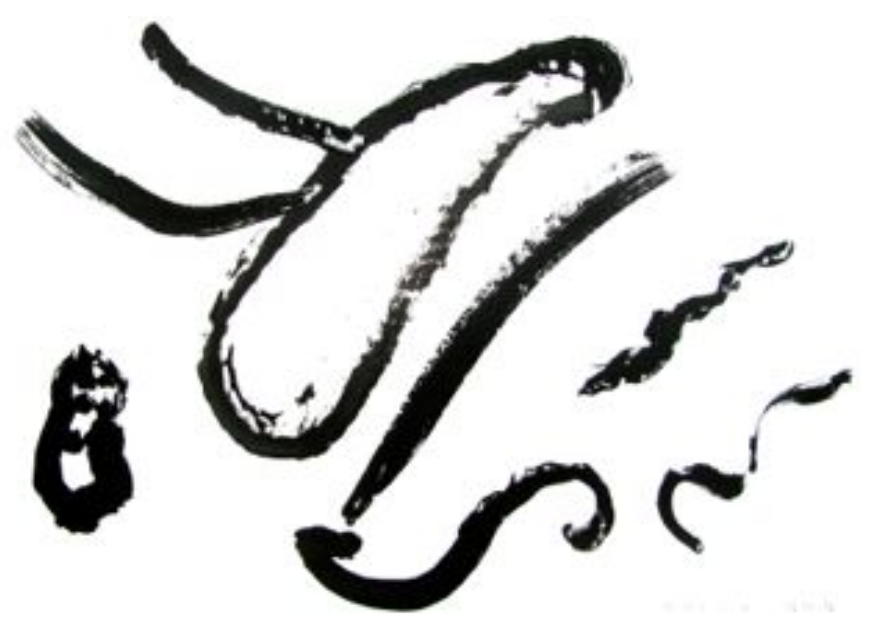

Kuva 7. Yhteinen maalaus. Tekniikka: akryyli paperille. Neljä tekijää.

Maalaus toteutettiin siten, että jokainen osallistuja vuorotellen maalasi yhteiselle pohjalle yhden siveltimenvedon. Tässä maalauksessa kukin henkilö on osallistunut kahdelle tällaiselle maalauskierrokselle. Paperille maalattiin siis kaiken kaikkiaan kahdeksan erillistä siveltimenjälkeä.

Paperille syntyy yhteinen sommitelma kahdeksasta erilaisesta viivasta, muodosta ja figuurista. Nostan kuvasta esiin kaksi yksityiskohtaa. Ensimmäisessä sama tekijä on liittänyt kaksi viivaa toisen tekijän maalaamaan pitkulaiseen ympyrämuotoon (kuvan vasen yläreuna). Sen voisi tulkita yhteisen hahmon rakentamiseksi, koska maalausjäljet asettuvat täsmällisesti toisen muodon yhteyteen. Toinen kiinnostava yksityiskohta on oikeassa alareunassa, jossa kaksi kiemuramuotoa asettuu vastakkain ikään kuin toisiaan peilaten. Niidenkin sijoittelun yhteydessä tulee väistämättä ajatelleeksi jonkinlaista muotojen kohtaamisen rakentamista. Sommitelma yhteisellä kuvapinnalla vaikuttaa tasapainoiselta ja erityisesti edellä poimitut yksityiskohdat harkituilta. Muutoin maalausjälkien asettuminen voi olla myös sattumanvaraista.

Maalaus on kuvallinen muistiinpano osallistujien kohtaamisesta. Tämän yhteisesti maalatun kuvan syntyprosessin erityisluonteen vuoksi se voidaan nähdä myös tietyn ryhmän erityisenä kohtaamisena, jolloin yhteinen maalaus lähestyy paikkasidonnaista yhteisöllistä taideprosessia. Jos tarkastellaan maalausta tekijöidensä näkökulmasta, paikan merkitys on ainutkertainen: yhteiset teokset eivät olisi syntyneet muussa kontekstissa.

Bergerin (2003: 173) mukaan sekä taiteella että keskustelulla on todellisuutta tuottava voima. Yhteisen taide-elämyksen äärellä osallistujat rakentavat kuvan avulla yhteistä todellisuutta. Filosofi Alfred Schütz on pohtinut sosiaalisen maailman rakentumista 
ympäristökohteista syntyvien yhteisten elämysten kautta: "Minun ympäristöni ja sinun ympäristösi, siis meidän ympäristömme on yhtenäinen ja yhteinen. - - - se on meille yhteinen intersubjektiivinen maailma, joka on tuossa edessämme" (2007: 302). Tämän kuvallisen maailman luomisessa osallistujilla on mahdollisuus osallistumiseen ilman kielellistä epäsymmetriaa. Yhteisellä paperilla liikutaan kenties visuaalisen intersubjektiivisuuden alueella.

\subsection{Yhteenveto}

Tässä artikkelissa käsitellyissä abstrakteissa kuvissa on erilaisia sattumanvaraiselta näyttäviä muotoja ja viivoja, joista on vaikea analysoida ja tulkita, mitä tekijät ilmaisevat kuvillaan. Erityisen haastavaa tämä on pääasiallisen kiinnostukseni kohteen, vuorovaikutuselementin, kannalta, koska tarkasteltavana oli vain kuvat ilman tekijöiden toiminnan tarkastelumahdollisuutta. Kuvista ei pysty erottamaan, mikä on afaattisen henkilön ja mikä läheisen tekemä jälki. Tämä on mielestäni keskeinen osallistumisen epäsymmetrian tasoittumiseen liittyvä havainto. Valitsin keskeiseksi tarkastelun kohteeksi kuvallisen työskentelyn aiheen ja motiivin. Tarkastelin kuva-aineistoa osallisuuden näkökulmasta. Syvensin osallisuuden tarkastelua Bergerin fenomenologisesti suuntautuneen tiedonsosiologian avulla. Se tutkii todellisuuden sosiaalista rakentumista. Kuvatilaan rakentuu osallistujille yhteinen merkityksellinen tila keskustelulle taiteen todellisuudessa. Tarkastelin maalauksia ja piirroksia jälkinä tekijöidensä eleistä ja eri tekijöiden ainutkertaisesta kohtaamisesta tässä tilassa. Teokset ovat syntyneet ei-sanallisen vuorovaikutuksen välttämättömyydestä ja tekijöiden kohtaamisesta arkitodellisuuteen verrattuna erilaisessa todellisuudessa, taiteen todellisuudessa (Berger 2003). Keskustelusta kiinnostuneelle taiteilijalle Bergerin ajatus sekä taiteen että keskustelun todellisuutta tuottavasta voimasta oli projektissa merkittävä.

Esitellyissä kuvallisissa tuotoksissa havaittava vuorovaikutus on tulkinnanvarainen. Projektissa toteutettuun ja tässä esiteltyyn kuvallisen työskentelyn tapoihin sisältyy kuitenkin implisiittinen odotus vuorovaikutuksesta tai yhteistyöstä. Vuorovaikutus voi toteutua eri yhteyksissä hieman eri tavoin. Kuvat ovat syntyneet kahdessa erilaisessa tilanteessa: Ensinnäkin tekijä jatkaa omassa työskentelyssään jonkun toisen tekemää kuvaa, jota nimitän alkukuvaksi. Toisessa tilanteessa tekijä on vuorovaikutuksessa toisen tekijän kanssa yhteisen paperin äärellä. Molemmissa tilanteissa implisiittinen odotus vuorovaikutuksesta ja kuvan elementteihin osallistumisesta luo teokselle pohjan. Tekijällä on mahdollisuus osallistua alkukuvan tarjoamaan kuvamaailmaan ja kehitellä omaa kuvallista aihetta haluamallaan tavalla.

Yhteisellä paperilla työskentelyn äärellä odotus vuorovaikutuksesta on alkukuvan työstämistäkin ilmeisempi. Osallistujien yhteinen työskentely jäsentää heidän keskinäistä vuorovaikutustaan symmetriseen suuntaan. Yhteisen paperin äärellä työskentely suuntautuu 
toinen toiselle ja tämä ilmausten vastavuoroisuus on kummankin samanaikaisesti koettavissa. Kuvien kommunikatiivinen ja taiteellinen luonne kietoutuvat toisiinsa, kun tekijät suhteuttavat tavalla tai toisella omat jälkensä toisen jälkiin yhteisellä paperilla. Maalausjäljistä syntyy aivan erityisiä kuvallisia muistiinpanoja osallistujien kohtaamisista. Tässä tapauksessa ne näyttäytyvät abstrakteina maalauksina.

\section{Pohdintaa}

Pohdin tässä taiteellisen lähestymistavan luonnetta ja kuvallisen työskentelyn merkityksiä ja mahdollisuuksia afasiaterapiaan liittyen. Nostan esiin seikkoja, jotka liittyvät kuvaan ja kieleen. Niiden välinen yhteistyö on erityisesti afasiaterapiassa keskeistä. Pohdin aluksi yhteiselle paperille tehtyjen kuvien tulkintaa ja sen jälkeen kuntoutukseen liittyviä näkökohtia.

\subsection{Kuvitelmia ja kohtaamisia kuvassa: Pohdintaa kuvien tulkinnasta}

Lukkarista (1990) mukaillen voin todeta, että tässä esitetyt kuvat ovat tuotoksia erilaisista tavoista liikkua paperilla, joka on tarjottu tilaksi vuorovaikutukselle ja yhteisille merkityksille. Näen kuvissa vuorovaikutusta ja sen eriasteisia representaatioita. Representaatio määritellään merkitysten tuottamiseksi mielessämme olevien käsitteiden avulla (Seppänen 2005: 77-82). Jos kynän tai siveltimen jäljissä voi nähdä jonkin esittävän kohteen, esimerkiksi puun, voidaan todeta, että kuvassa on puun representaatio. Representaatio viittaa siihen käsitteelliseen prosessiin, joka jäsentää havaintomme mielekkääksi. Se on abstraktion prosessi, joka välittää havaitsemisen konstruktioksi (Kuusamo 1990: 52). Tässä käsitellyissä kuvat eivät esitä selkeästi mitään ulkomaailman kohteita, vaan ovat abstrakteja. Amerikkalaiselle kuvataiteilijalle Agnes Martinille (1996) abstrakti maalaus on tie tiedostamattomiin tunteisiin. Abstrakti kuva viittaa tekijän mieleen tavalla tai toisella. Mielestäni abstrakti kuva voi esittää myös tekijöiden välistä vuorovaikutusta.

Abstraktin ja esittävän kuvan erottelua on kritisoitu. Kuusamo (1990: 87-88) käsittelee taidehistorioitsija E. Gombrichin (1960) kritiikkiä siitä, että esittävä olisi ulkoista ja abstrakti sisäistä. Tämä kritiikki on erittäin kiinnostava sen väitteen kannalta, että yhteisesti rakennettu kuva olisi sen tekijöiden välisen vuorovaikutuksen representaatio. Eri tekijöiden tekijän yhteisesti tekemästä abstraktista maalauksesta tai piirustuksesta on voinut tulla tekijöiden välistä vuorovaikutusta esittävä kuva tai vuorovaikutuksen representaatio, vaikka sitä ei välttämättä sellaiseksi aiottu. Kiinnostavaa on, että renessanssiteoreetikot erottelivat sisäisen ja ulkoisen piirustuksen. Kädenjälki antaa suoran näkymän taiteilijan mieleen. Ulkoinen piirustus on vain taiteilijan mielen sisäisen piirustuksen materialisaatio (Lukkarinen 2015: 16). 
Kuusamo (1990: 15-16) toteaa, että odotukset ja havaintotottumukset vaikuttavat niin taiteilijan kuin taiteen katsojan havaintoihin. Tämä havaitsemisprosessi onkin kiinnostava tilanteessa, jossa kaksi tekijää työskentelee yhteisen paperin äärellä. Tällöin tilanteeseen sisältyy implisiittisesti ainakin odotus vuorovaikutuksesta tai yhteistyöstä. Yhteisestä kuvallisesta kompositiosta löytyvä vuorovaikutus on tulkinta. Kuten aiemmin totesin, aineistoni sinisestä ja keltaisesta rakentuvissa maalauksissa maalausjälkien kohtaamiset voivat olla myös sattumanvaraisia. Maalauksia katsoessa on kuitenkin vaikea välttyä ajattelemasta siveltimen vetojen välistä kohtaamista sekä muotojen ja värien välistä vuorovaikutusta, joka on ilmeistä varsinkin maalauksissa, jossa värit sekoittuvat.

Havaintosysteemimme etsii kuvasta merkityksiä automaattisesti. Ajattelumme ja arvostustemme mekanismeihin yhteydessä oleva symbolisen systeemimme jäsentää kuvaa. Kuusamo $(1990: 11,15,17)$ pohtii tulkinnan problematiikkaa: Onko välitön muodon kokeminen mahdollista? Voiko tulkinta tapahtua "viattomiin" visuaalisiin muotoihin ja sommitteluun liittyvän tiedon varassa vai ratkaiseeko tulkinta sen avulla minkä tulkitsija tuo ulkoapäin? Kuusamo (1990: 111) toteaa, että muodon havaitsemiseen vaikuttaa paitsi muoto itse, myös se mitä on sen ympärillä. Samanlainen viiva piirustuksessa voi merkitä eri asioita. Se voi kuvata hahmon materiaalisuutta, erotella, rajata, jakaa tai yhdistää. Kuvan muotojen tulkintaan voivat vaikuttaa erilaiset käsitteelliset esioletukset. Esimerkiksi psykoanalyytikko voi tulkita muotoja kyseiseen teoriaan liittyvinä symboleina (Kuusamo 1990: 15).

Historiasta löytyy kiinnostavia näkökulmia kuvien tulkintaan. 1700-luvun Venetsiassa tehtiin Capriccio-maalauksia, joissa yhdisteltiin maisema- ja arkkitehtuurifragmentteja ja satunnaisia ihmisfiguureja. Niissä taiteellinen ilmaisu oli tärkeämpää kuin perinteinen aihe, jonka sisältö ja merkitys jäivät tarkoituksellisesti arvoituksiksi. Katsoja saa lopulta päättää mitä tällainen taideteos merkitsee (Lukkarinen 2015: 39). Samoihin aikoihin 1700-luvun Englannissa venäläissyntyinen maisemamaalari Alexander Cozens kehitti maalausmenetelmän, joka perustui musteläiskistä syntyviin satunnaisiin muotoihin, jotka eivät esittäneet mitään. Ne kantoivat itsessään katsojalle mahdollisuuden luoda assosiaatioita maisemallisuuteen. Cozens (1785; ks. myös Lukkarinen 2015: 24) viittaa musteläiskämaalausten yhteydessä Shakespearen säkeisiin, joissa puhutaan pilvissä nähtävistä lohikäärmeistä, eläimistä linnoista ja vuoristomaisemista. Yhtymäkohtia on myös Leonardo da Vincin tapaan tarkastella pilviä ja nähdä niissä esimerkiksi taisteluita. Tässä artikkelissa esitellyistä kuvaesimerkeistä meillä on mahdollisuus luoda assosiaatioita tekijöiden väliseen vuorovaikutukseen. Alkukuvan ja maalauksen sommitelmat tarjoavat katsojalle puolestaan tilaisuuden nähdä olioita, akvaarioita, haarautuvia oksia, kukkamaljakoita, kehonrakentajia ja kenties jopa talo, johon johtaa tie. 
Kuvateoksen nimellä voi olla suuri vaikutus siihen, miten näemme kuvan. Kuusamo (1990: 17) toteaa, että usein nimi viittaa teoksen "sisältöön" silloinkin, kun suoraa esittävää vihjettä ei ole. Projektissa tekijöitä ei ohjailtu nimeämällä alkukuvia tai muutoin antamalla vihjeitä, jotka olisivat voineet ohjata kuvan tulkintaa. En ole nimennyt kuvia "johdattelevasti" myöskään tässä artikkelissa, vaan pyrkinyt "neutraaliuteen". Esimerkiksi olen säilyttänyt hiilipiirrokselle jälkeenpäin annetun työnimen Hiilijälkiä. Toinen neutraali nimi voisi olla Viivoja ja palloja. Olisiko Viivojen ja pallojen vuorovaikutusta enää neutraali nimi? Vuorovaikutteisessa tekoprosessissa tekijöillä on oma rooli, josta pidetään sopimuksenvaraisesti kiinni. Tekijöiden sopimus säilyy kuvapinnan täyttymiseen saakka: toinen piirtää pallot ja toinen viivan. Sopimus sallii pienet variaatiot viivojen muodossa ja pallojen sijoittelussa.

Abstraktin taiteen idean jatkeena syntynyt minimalismi sisältää kiinnostavan ajatuksen siitä, miten useat minimalistiset teokset tutkivat materiaaliensa ominaisuuksia. Vuorovaikutus on erityisen vahvasti erityisesti Hiilijälkiä-piirroksen todellisuutta. Se materialisoituu voimakkaasti kuvassa ja kenties hieman minimalismin määritelmää omintakeisesti hyödyntäen tulin pohtineeksi, voisiko asian ilmaista peräti niin, että vuorovaikutus olisi kuvan materiaalia. Voiko aineeton olla materiaalia?

\subsection{Taidekuva ja terapian uudet tuulet: Pohdintaa kuvan ulottuvuuksista ja merkityksistä afasiakuntoutuksessa}

Projektin aikana tekemieni havaintojen inspiroimana aloin pohtia tarkemmin kuvan tekemisen merkityksiä ja mahdollisuuksia afasiakuntoutuksessa. Kuten Koskinen (2019:105) toteaa, taiteilijan erityinen lähestymistapa voi näyttää uudessa valossa myös käytettyjä menetelmiä. Kuvallisten tehtävien suunnittelu ja materiaalien valmistaminen vaikuttivat ajatuksiini terapiassa käytettävästä materiaalista ja erityisesti kuvista. Voitaisiinko kuvallisesta työskentelystä kehittää afasiakuntoutukseen sekä kommunikaation että kielen kuntouttamiseen luovia menetelmiä, joissa kuvallisuus saisi erilaisia ulottuvuuksia, joita voitaisiin käyttää terapiassa kiinteässä kielellisiin merkityksiin yhteydessä olevien kuvien rinnalla.

Machinin mukaan kuvat eivät ole yhtä selkeästi identifioitava tutkimusalue kuin kieli. Kuvasta ei aina voida puhua vain yhtenä kanavana (Machin 2009: 182; Kress 2009: 58 59). Kuviksi voidaan lukea niin valokuvat, abstraktit maalaukset, mekaaniset piirrokset, kaaviokuvat kuin peilikuvakin. Englanninkielinen sana image sisältää vielä laajemman tarkoitteiden kirjon, sillä se viittaa myös esimerkiksi muistikuviin, käsityksiin ja kielikuviin.

Vaihtoehtoisessa kommunikaatiossa (Augmentative Alternative Communication, AAC) kuva on rakennettu kommunikaatiotyökaluksi (esim. Von Tetzchner \& Martinsen 1999). Terapiamateriaalina kielellisten funktioiden arvioimiseen ja kielellisen ilmaisun 
aktivoimiseen käytettävät kuvat ovat perinteisesti kiinteässä yhteydessä kielellisiin merkityksiin: esimerkiksi esinekuvat kuvaavat substantiiveja ja toimintakuvat verbejä. Code (2017: 7) nostaa esiin Myersin 80-luvulla esittämän ajatuksen, että afasian kuntoutuksessa tulisi käyttää stimuloivaa materiaalia, joka ruokkisi mielikuvitusta ja "valjastaisi monimutkaisia suhteita ja vuorovaikutuksia ja synnyttäisi rikkaita assosiaatioita" eikä pelkästään konkreettisten objektien kuvia. Juuri taide voi tarjota paitsi mahdollisuuksia rikkaisiin assosiaatioihin ja hedelmällisiä näkökulmia myös kielellisen ja kuvallisen erojen ja yhteyksien pohdiskelulle. Terapiassa perinteisesti käytettävässä materiaalissa kuvan sisältö liittyy kiinteästi kielellisiin merkityksiin. Tällainen on varmasti perusteltua. Voisiko kielellisistä merkityksistä irtoaminen ja vapaa kuvallinen ilmaisu mahdollistaa kytköksiä luovuuden ja kielen sekä kielellisten prosessien välillä ja jos niin mihin se perustuu?

Barthesin kuvien semioottisen analyysin teorian käsitteet denotaatio ja konnotaatio (Barthes 2002: 136) selventävät joiltain osin kuvallisen työskentelyn kehittämisen ja laajentamisen ajatusta afasiaterapiassa. Barthes määrittelee denotaation merkityksen olevan sama kuin kuvan kielellinen vastine, jonka hän pystyy tunnistamaan ja kuvailemaan. Se rakentuu katsojalle hänen aikaisempien tietojensa perusteella. Tämä on afasiakuntoutusmateriaalissa keskeinen piirre, jota käytetään kielellisten funktioiden arvioinnissa ja terapiassa. Kuviin liittyy kuitenkin myös sivumerkitys eli konnotaatio, jonka avulla välitetään esimerkiksi mielikuvia sen kautta mitä ja miten asiaa representoidaan. Konnotaatio liittyy omiin kulttuurisiin assosiaatioihin ja syntyy kulttuurillisten merkitysten (ja kokemusten) pohjalta (Seppänen 2005: 116-117). Terapiassa voitaisiin kenties liikkua kuvien kanssa denotaatio-konnotaatio-jatkumolla ja hyödyntää kuvien merkityksen kerroksellista rakentumista. Taiteellisen työskentelyn liittäminen kuvalliseen työskentelyyn mahdollistaisi juuri runsaan mielikuvien aktivoinnin ja kuvittelukyvyn kehittämisen. Edelleen, kuten Barthes on todennut, kuvan merkityksiä voidaan tarkentaa tekstillä, mikä on myös terapiakontekstissa luonteva asia (2002).

Kuva ja sanan eroja käsitellessään Kuusamo (1990: 52-53; 76-77) toteaa: "Kuvat ovat semioottisia systeemejä, jotka eivät perustu yksiköille. Maalauksen systeemi on avoin vastakohtana kielen suljetulle systeemille. Maalaus sisältää itsessään semanttiseen tarkoitteisiin viittaavan ulottuvuuden." Myös Mikkonen (2005) on käsitellyt kuvan ja sanan eroja. Nostan tässä esiin Kuusamon muotoilua täsmentävän luonnehdinnan kuvan ja kielen eroista: kuvaan liittyvän ajallisuutta ja toimintaa koskevan järjestyksen on avoimuuden. Näen tämän piirteen juuri mahdollisuuksia avaavana. Mikkosen esittämien muiden erojen pohtiminen jatkossa olisi kiinnostavaa. Kiinnostava on myös Mikkosen ajatus kuvan ja sanan suhteen välisistä merkityksen aukoista. Ne liittyvät kuvakirjan kuvitukseen. Kuvakirjassa kuva on liitetty täydentämään tekstiä. Aukot ovat täydennettävissä laajemman tulkinnallisen viitekehyksen, 
kuten kertomuksen kautta (Mikkonen 2005: 93-94). Viitekehys voisi mielestäni olla myös kuvallinen.

Terapiamateriaalin kehittelyyn voisi liittyä paitsi luova ote kuvallisiin merkityksiin myös pohdiskelu sanan ja kuvan yhteismerkityksistä. Terapian kannalta keskeisiä kysymyksiä ovat esimerkiksi, miten kielelliset merkitykset yhdistyvät kuviin ja mikä on kuvien ja sanojen yhteinen sivumerkitys- eli konnotaatiopotentiaali (Kuusamo 1990: 201-203). Kuva ja sana voivat olla väljässä semanttisessa suhteessa toisiinsa. Kielen ja kuvan väljä suhde sallii suuren sivumerkityksellisen pelivaran. Kahden merkkijärjestelmän yhtäaikainen käyttö on mahdollista esitajuisen kulttuurisen koodauksen avulla (Kuusamo 1990: 196-197). Esimerkiksi erittäin huolellisesti rakennetuilla mainoskuvilla pyritään herättämään tai aktivoimaan esitajuisia systeemejä, joissa koodaus käyttää samoja tajunnan funktioita kuin esimerkiksi vitsien ymmärtäminen (Kuusamo1990: 198, 201). Voitaisiinko terapiamateriaalin kehittelyssä kenties hyödyntää samanlaisia prosesseja?

Terapia-ajattelu on laaja-alaista ja osallisuutta korostavaa. Samaan aikaan on lisääntynyt myös monialainen yhteistyö, jossa tieteen ulkopuolelta haetaan asiantuntemusta (Koskinen 2019: 97). Terapiamenetelmät ovat monipuolistuneet ja niihin liittyvä tutkimus on lisääntynyt. Taiteen käyttöä hoitotyössä tutkintaan (esim. Lehikoinen 2017). Monissa afasiaterapiamenetelmissä painopisteenä on afaattisen ihmisen osallistumisen lisääminen arkielämässä, osallisuus, inmissuhdekeskeisyys ja täysipainoinen elämä afasiasta huolimatta (Worrall 2018). Neuropsykologisessa kuntoutuksessa taidemenetelmiä voidaan käyttää monin eri tavoin sekä ryhmä- että yksilöterapiassa kuntoutuksen jokaisessa vaiheessa (Ranta 2011a). Neuropsykologinen tutkimus sisältää monia kuvan tekemiseen ja havainnointiin liittyviä tehtäviä. Kuvallisen materiaalin avulla on kuntoutettu erityisesti näkömuistin ja visuaalisen hahmotuksen häiriöitä (esim. Wilson ym. 2017). Ranta (2011b) on luonut kiinnostavan katsauksen visuaalisen tiedon prosessoinnista. Hän sivuaa siinä muun muassa sen yhteyksiä eri aivoalueille sekä "mieleen".

Visuaalisuutta on hyödynnetty vuorovaikutusta arvioivissa diagnostisissa strukturoiduissa tehtävissä, kuten esimerkiksi kontaktipiirustuksessa (Grätz 1978). Kiinnostavan näkökulman tarjoaa Anna-Riitta Putkosen kehittämä kuvan tekemiseen perustuvan piktogrammimenetelmä, jolla tutkitaan emotionaalisesti latautuneen käsitteen subjektiivista ja visuaalista vastinetta ja mielikuvaa sekä ajattelun adekvaattisuutta ja koherenssia (Christensen 1982). Wilson (2001) on käsitellyt symbolisaatioprosessin häiriöitä aivovamman yhteydessä ja miten taideterapialla on voitu vaikuttaa kielenkäyttöön ja objektisuhteisiin. Tältä alueelta ei juurikaan tutkimusta ja olisi kiinnostavaa edelleen pohtia, miten kuvatyöskentely voitaisiin räätälöidä yksilöllisesti afasiaterapiassa kuntoutujan tarpeisiin tukemaan juuri hänen kielellisen häiriön problematiikasta toipumista. Myös läheisen sopeutumisen tukeminen erilaisin 
taideterapeuttisin keinoin on mahdollista. Tämä olikin yhtenä tavoitteena hankkeessamme, jossa myös läheiset olivat mukana. Kuvallisella työskentelyllä voi olla myös faattinen, ilmaisukanavaa ja vuorovaikutusta ylläpitävä tehtävä, jossa ei välitetä varsinaista tietoa (Jakobson 1996). Tiedon välittyminen taiteessa ei ole samanlaista, mutta tarjoaa uuden tavan tulla ymmärretyksi. Vuorovaikutustilanteissa ei välttämättä vaadita täydellistä ymmärtämistä aina kielenkään osalta. Oleellisinta voi olla kokemus siitä, että on tullut kohdatuksi. Visuaaliset keinot tarjoavat sellaisia semioottisia ja kognitiivisia resursseja, joita ei ole kielessä. "The characteristics of the medium of air are not the same as those of the medium of stone, and the potentialities of the speech organs are not the same as those of the human hand." (Kress 2005: 34).

Taide itsessään on kokeilevaa ja etsivää toimintaa. Kuvataide on ollut jossain määrin tutkivaa jo Leonardo Da Vincin ajoista saakka (Koskinen 2019: 103). Erityisesti piirtäminen on suunnittelun, keksimisen ja löytämisen menetelmä (Lukkarinen 2015: 16). Kuvataiteellinen työskentely on afaattiselle henkilölle suhteellisen helposti saavutettavaa toimintaa. Hänen taiteellinen toimijuutensa pääsee toteutumaan, kunhan sille luodaan sopivat puitteet ja luodaan saavutettavia tilanteita, joissa toimintarajoitteet otetaan huomioon. Piirtäminen ja maalaaminen ovat yksinkertaisia menetelmiä, jotka "herkistävät tekijän aistimelliseen suhteeseen ympäristön kanssa", kuten Lukkarinen (2015: 17) on muotoillut. Meidän tapauksessamme kuvallinen työskentely herkisti piirtäjän aistimelliseen suhteeseen toisen piirtäjän kanssa. Alkukuvaa yksin työstäessään kuvapinnan elementtien vuorovaikutus rakentuu ajallisesti eri tavalla kuin kuvissa joissa molemmat tekijät ovat yhtä aikaa kuvan äärellä. Toisaalta tilanteissa on samankaltaisuutta siinä, että myös oltaessa yhteisen paperin äärellä jälkimmäinen tekijä osallistuu kuvaan, jossa on ensimmäisen tekijän tekemä jälki. Kasvokkainen vuorovaikutuksellinen kuvatyöskentely voi olla erittäin motivoivaa, koska siten voidaan ylittää osallisuuden esteitä, joita afaattisilla henkilöillä ovat syrjäytyminen toisten yhteydestä, ymmärtämisen, sanoittamisen ja kuulumisen (eli viestin näkyville saamisen) vaikeus. Kuvallisen työskentelyn kautta osallistuja tulee nähdyksi ja hyväksytyksi.

Projekti avasi polkuja uudenlaisille lähestymistavoille ja mahdollisuuksille kielellisessä kuntoutuksessa ja sen tutkimuksessa. Afasian oirekuvasta riippuen työskentely voisi perustua pelkästään kuvalliseen työskentelyyn tai siihen voisi liittää kielellistä ainesta. Alkukuvatyöskentelyssä tekijä on vuorovaikutuksessa kuvamateriaalin kanssa. Menetelmällä voisi olla mahdollisuuksia kielellisen ilmaisun sananlöytämisen ja lauseiden rakentamisen fasilitoinnissa sekä yksilö- että ryhmäterapiassa myös vaikeissa oirekuvissa. Alkukuvalle rakennetut sommitelmat voivat aktivoida vuorovaikutusta ryhmätilanteissa ja toimia alustana keskustelulle silloin, kun oirekuva lievä. Projektissa teimme maalausten ja piirustusten lisäksi myös kuvakollaaseja ja sekatekniikkakuvia. Jatkossa olisi kiinnostavaa tutkia eri välineiden ja 
tekniikoiden merkitystä, samoin kuin esittävän ja ei-esittävän kuvamateriaalin erilaisia mahdollisuuksia. Projektissa toteutettujen tehtävien pohjalta voi suunnitella kokonaan uusia lähestymistapoja. Soveltavan kielentutkimuksen kentällä kielen oppimisessa on ollut käytössä erilaisia visuaalisia lähestymistapoja, joista Kalaja ja Pitkänen-Huhta (2018) ovat luoneet laajan katsauksen. Kuvallinen työskentely, kutsuimmepa sitä sitten luovaksi ilmaisuksi tai taiteeksi, voi tarjota rikkaan alustan itseilmaisulle ja vuorovaikutukselle. Sen kautta afaattinen henkilö voi tehdä itsensä näkyväksi ja motivoitua ilmaisemaan itseään. Hän voi saada uusia kokemuksia myös siitä, että lähi-ihmiset ymmärtävät hänen ilmaisuaan. On tärkeää, että afaattinen henkilö saa ilmaista itseään mahdollisimman monilla eri keinoilla ja varsinkin niillä, jotka toimivat hyvin.

Afasia ei ole pelkkä kielellinen häiriö, vaikka ilmenee kielessä (esim. Ansaldo ym. 2016). Kielellinen prosessointi ei ole mahdollista ilman sitä tukevia kognitiivisia funktioita. Afasiassa on kyse performanssin ongelmasta. Tämä on tuttua afasian terapiakäytänteissäkin lurijalaisen neuropsykologisen kuntoutuslähestymistavan pohjalta (esim. Christensen 1982). Afasiaterapiassa on vain vähän evidenssiä siitä, että pelkkä kielelliseen malliin perustuva kuntoutus olisi toimivaa, sen sijaan muunlaisen kuntoutuksen vaikuttavuudesta on. Vaikuttaviksi tekijöiksi on todettu intensiteetti ja fasilitaatio riippumatta mihin kielelliseen alueeseen se kohdistuu (esim. McNeil ym. 2011). Näin ollen olisi kiinnostavaa pohtia, mitä taide, teoriassa ja käytännössä, voisi antaa afasian kuntoutukselle.

\section{Lopuksi}

Taiteella voi lähestyä sellaisia kokemuksia, näkökulmia ja kysymyksiä, jotka kaipaavat vielä tieteellistä huomiota. Toteuttamani projekti syntyi taiteellisesta uteliaisuudesta ja toteutui taiteellisella tutkimusotteella. Siksi tarkastelin tässä aineistoani pitkälti taiteellisista lähtökohdista käsin: miten taide voi näyttäytyä osana sosiaalista todellisuutta? Koskisen mukaan taiteen tarkoitus on nostaa esille ilmiöitä ja näkökulmia ja esittää myös sellaisia kysymyksiä, joihin tutkimuksella voisi pyrkiä vastaamaan (Koskinen 2019). Pyrin avaamaan artikkelissani taiteentutkimuksen, kielentutkimuksen ja afasiatutkimuksen rajapintoja ja kohdentamaan pohdiskeluni tieteellisesti relevantteihin seikkoihin.

Pohdittaessa, voisiko kuvataiteen tekemisellä olla annettavaa afasian kuntoutuksessa, mielestäni keskeinen kysymys liittyy siihen, mitä neurologiseen kuntoutumiseen vaikuttavia relevantteja resursseja ja proseduureja kuvataiteellinen työskentely koskettaa. Ja edelleen: Mihin muuhun kuin emotionaaliseen tilaan kuvataiteen tekeminen voi vaikuttaa? Miten "elämyksellisyys" vaikuttaa toiminnan ohjaukseen? Miten aktiivinen taidetyöskentely on yhteydessä kieleen ja kognitiivisiin toimintoihin? Mikä yhteys on visuo-spatiaalisella 
prosessoinnilla kielellisiin prosesseihin? Koskettaako kuvallinen työskentely esimerkiksi sellaisia oikean aivopuoliskon toimintaan liitettyjä kielellisiä funktioita kuten kontekstisidonnaisia kielellisiä ilmauksia, kuten vitsejä, metaforia, epäsuoraa puhetta, semanttista erottelua sekä puheen sävelkulkuun liittyvää prosessointia? Auttaako tietyntyyppisten kuvien käyttö sanojen aktivoinnissa? Ehkä jotkut näistä kysymyksistä päätyvät tulevaisuudessa tutkimuksen kohteeksi.

Erilaisten kuvallisten kompositioiden inspiroimana pohdin myös afasiakuntoutuksen kannalta keskeisten kuvallisten ja kielellisten resurssien problematiikkaa. Taide metodologisena välineenä avasi näkökulman, joka arvioi nykyisten afasiakuntoutusmateriaalien luonnetta ja erityisesti kuvallisten resurssien ja käytänteiden kehittämistä afasiakuntoutuksessa. Siinä tarvitaan varmasti monitieteistä otetta. Myös erilaisten kuvien aktiivinen tuottaminen voisi olla hedelmällinen tutkimuskohde eri näkökulmista. Aivotutkimusta on jo tehtykin elokuvan vastaanottokokemukseen liittyen (esim. Pihko 2011; Pamilo ym. 2012). Kuvallisuuteen liittyvän tutkimuksen kohteena on ollut ainakin kuvan tulkinnan ja semanttisen prosessoinnin yhteys (esim. Luotonen ym. 2019). Kognitiivisista neurotieteen uusista menetelmistä voi olla toivoa tulevaisuuteen sekä terapeuttisesti että tutkimuksellisesti.

Projektissa syntynyt taide tuotti ideoita ja erilaisia näkökulmia myös tutkimuksen tekemiseen. Aluksi näin yhteisesti rakennetut kuvat taiteen todellisuudessa kumpuavina kuvallisina keskusteluina. Niin kiehtovalta kuin tämä kuulostikin, totesin hyvin pian, että keskusteluntutkimuksen lähestymistavasta ei löydy siihen tarvittavia työkaluja - niin luontevaa kuin ei-kielellisen vuorovaikutuksen ja olemuskielen tutkimus onkin. Olemuskieli on tärkeä paitsi varhaisessa vuorovaikutuksessa, se voi olla tärkeä myös silloin, kun ihminen menettää kyvyn kielelliseen ilmaisuun. Olemuskieleen kuuluvat esimerkiksi katse, kehon asennot ja liikkeet, toiminta, ilmeet ja eleet, ääntely ja äänensävyt, äänen painot, itku ja nauru. Myös toiminnan nopeus ja rytmi, esim. hengitysrytmi kuuluvat olemuskieleen (Pulli ym. 2005). Groszin (2008) ajatukset aavikkomaalauksista ruumiillisuuden, voiman, liikkeen ja rytmin suorana ilmaisuna liittyvät kiinnostavalla tavalla olemuskieliseen ilmaisuun, johon kuuluu myös rytmi ja liike. Näen kuvalliseen ilmaisuun sisältyvän olemuskielen piirteitä myös tässä aineistosta, mutta sen tarkastelu on kuitenkin haastavaa. Jatkossa kenties voitaisiin tutkimuksella päästä tarkastelemaan paitsi kuvallisen työskentelyn aikana ilmenevää olemuskieltä myös kuvalliseen ilmaisuun sisältyviä olemuskielen elementtejä, kuten rytmiä, nopeutta tai kuvassa ilmenevää liikettä. Kuvapinnassa ilmenevää rytmiä onkin jo tarkasteltu (esim. Kress ja Leeuwen 2005; Rose 2001). Joissain tapauksissa henkilö voi myös menettää kyvyn tunteiden tai olemuskieliseen ilmaisuun, jolloin kuvallinen olemuskieli on ainoa ilmaisukeino.

Abstraktien jälkien tarkastelussa voitaisiin jatkossa keskittyä tarkemmin kuvan visuaalisten piirteiden formaalien elementtien väliseen vuorovaikutukseen. Elementtien välisten 
suhteiden lisäksi voidaan tarkastella elementtien sijaintia, kokoa, etäisyyttä, läheisyyttä, figuureja ja muotojen samanlaisuutta. Rosen (2001: 40) lähestymistavassa sivutaan hieman myös elementtien välistä vuorovaikutusta. Kress ja Leeuwen ovat tarkastelleet kuvan tilallista rakentumista katsojan näkökulmasta. Kuvallisen analyysin kohteena aiheen lisäksi voivat olla myös väri (sävy), värikylläisyys (intensiteetti) valööri (valoisuus) sekä harmonian luominen (Kress ja Leeuwen 2005: 79-118). Myös abstraktin ja esittävän kuvan sekä olemuskielen ja kielen välisten suhteiden tarkastelu jatkossa olisi kiinnostavaa.

Jatkossa empiirisellä tutkimuksella voitaisiin lisätä käsitystä kuvataiteellisen työskentelyn ilmiöistä. Bergerin näkemykset yksilön kokemusmaailmasta ovat kiinnostavia, koska ne sivuavat myös vuorovaikutuksen metodologiaa (Berger 2003: 217). Kuvapinnalla tapahtuvia kuvallisia kohtaamisia ja osallistujien orientaatioita voitaisiin jatkossa tarkastella myös multimodaalisena ajallisesti rakentuvana toimintana. Tällainen toimintaan keskittyvä lähestymistapa täydentäisi tämän artikkelin keskiössä olevan aiheen tarkastelua ja toisi lisää ymmärrystä siihen, millä tavoin yhteinen paperi voi olla kenttä tehdä kokeita visuaalisesta intersubjektiivisuudesta puhtaan taiteen parissa.

\section{Kiitokset}

Kiitän yhteistyöstä Itä-Savon AVH- ja afasiayhdistystä sekä Suomen Kulttuurirahastoa. Taidetta hoitolaitoksiin -apuraha mahdollisti kuvataideprojektin, jonka kuvallisia tuotoksia käsittelen tässä artikkelissa.

\section{Kirjallisuus}

Ansaldo, U. \& N. J. Enfield 2016. Editorial: Is the language faculty nonlinguistic? Frontiers in Psychology 7, 861. https://doi.org/10.3389/fpsyg.2016.00861

Barthes, R. 2002. Rhetoric of the image. Teoksessa N. Mirzoeff (toim.) The visual culture reader. 2. painos. London: Routledge, 135-138.

Berger, P. L. \& T. Luckmann 2003. Todellisuuden sosiaalinen rakentuminen: Tiedonsosiologinen tutkielma. 3. painos. (suomentanut V. Raiskila 1994). Helsinki: Like. Alkuperäisteos 1966 The social construction of reality: A treatise in the sociology of knowledge.

Code, C. 1981. The role of the right hemisphere in the treatment of aphasia. Teoksessa R. Chapey (toim.) Language intervention strategies in adult aphasia. Baltimore: Williams \& Wilkins, 380-386.

Christensen, A.-L. 1982. Lurian neuropsykologinen tutkimus. Käsikirja. Helsinki: Psykologien kustannus Oy. 
Cozens, A. 1785. New method of assisting the invention in drawing original compositions of landscape. Transkriptio teoksessa A. P. Oppé 1954 Alexander and John Robert Cozens. Cambridge, Mass.: Harvard University Press, 165-87; uusintapainos transkriptiosta teoksessa J. C. Taylor (toim.) 1987. Nineteenth-century theories of art. Berkeley, Los Angeles, London: University of Califormia Press, 63-71.

Forssell, A. 2008. Kun sanat puuttuvat tai eivät riitä - kuva voi tulla tilalle. Teemanumero Taideterapia neurologisten potilaiden kuntoutuksessa. Taideterapia. Suomen Taideterapiayhdistyksen jäsenjulkaisu v. 2008. Espoo: Suomen taideterapiayhdistys ry, 19-22.

Gombrich, E. H. 1960. Art and illusion: A study in the psychology of pictorial representation. New Jersey: Princeton University Press

Grosz, E. 2008. Chaos, territory, art. Deleuze and the framing of the earth. New York: Columbia University Press.

Grätz, E. 1978. Zeichnen aus dem Unbewußten als anamnestische, diagnostische, therapeutische und pädagogische Methode. Stuttgart: Hippokrates

Isola, A.-M., H. Kaartinen, L. Leemann, R. Lääperi, T. Schneider, S. Valtari \& A. Keto-Tokoi 2017. Mitä osallisuus on? Osallisuuden viitekehystä rakentamassa. Terveyden ja hyvinvoinin laitos, työpaperi 33/2017. http://urn.fi/URN:ISBN:978-952-302-917-0

Jakobson, R. 1996. Closing statement: Linguistics and poetics. Teoksessa J. J. Weber (toim.) The stylistics reader: From Roman Jakobson to the present. London: Arnold, 36-53.

Kalaja, P. \& A. Pitkänen-Huhta 2018. ALR special issue: Visual methods in applied language studies. Applied Linguistics Review, 9 (2-3), 157-176. https://doi.org/10.1515/applirev-2017-0005

Koskinen, I. 2018. Miksi tieteilijöiden kannattaa tehdä yhteistyötä taiteilijoiden kanssa. Ajatus. 75, Suomen filosofisen yhdistyksen vuosikirja. Tampere: Juvenes Print, 93-120

Kuusamo, A. 1990. Kuvien edessä. Helsinki: Gaudeamus.

Kress, G. 2009. What is mode? C. Jewitt (toim.) The Routledge handbook of multimodal analysis. Abingdon, New York: Routledge, 54-67.

Kress, G. \& T. van Leeuwen 2005. Reading images. The grammar of visual design. Abingdon, New York: Routledge, 79-118.

Lehikoinen, K. 2017. Justifying the arts in health and care in Finland: A discourse analytic inquiry. Cogent Arts \& Humanities 4(1), 1-12.

Lukkarinen, V. 2015. Piirtäjän maisema. Helsinki: SKS.

Luotonen, I., K. Renvall \& P. Korilahti 2019. Semanttiset tehtävät aikuisten neurologisten häiriöiden arvioinnissa: terveiden ikääntyneiden ja Alzheimerin tautia sairastavien henkilöiden suoriutuminen. Teoksessa S. Loukusa, A.-K. Tolonen, A. Nylund \& A. 
Kautto (toim.) Kehityksellisen kielihäiriön monet kasvot 2019. Helsinki: Puheen ja kielen tutkimuksen yhdistyksen julkaisuja 51.

Machin, D. 2009. Multimodality and the theories of the visual. Teoksessa C. Jewitt, (toim.) The Routledge handbook of multimodal analysis. Abingdon, New York: Routledge, 181190.

Martin, A. 1996. The untroubled mind. Teoksessa K. Stiles \& P. Selz (toim.) Theories and documents of contemporary art. Berkeley: University of California Press, 128-137.

Merleau -Ponty, M. 2012. Filosofisia kirjoituksia. (Toim. ja suom. M. Luoto \& T. Roinila). Helsinki: Nemo.

McNeil, M, W. Hula \& L. E. Sung 2011. The role of memory and attention in aphasic language performance. Teoksessa J. Guendouzi, F. Loncke \& M.J. Williams (toim.) The handbook of psycholinguistic and cognitive processes. Hove, East Sussex: Psychology Press, 551-577.

Myers, P. 1980. Visual imagery in aphasia treatment: a new look. Teoksessa R. H. Brookshire (toim.) Clinical aphasiology conference proceedings. Minneapolis: BRK Publishers, 6877.

Pamilo, S., S. Malinen, Y. Hlushcuk, M. Seppä, P. Tikka \& R. Hari 2012. Functional subdivision of group-ICA results of $\mathrm{fMRI}$ data collected during cinema viewing. PLoS One. 7 (7), e42000. https://doi.org/10.1371/journal.pone.0042000

Pihko, E., A. Virtanen,V.-M. Saarinen, S. Pannasch, L. Hirvenkari, T. Tossavainen, A. Haapala \& R. Hari 2011. Experiencing art: the influence of expertise and painting abstraction level. Frontiers in Human Neuroscience 5, 94. https://doi.org/10.3389/fnhum.2011.00094

Pulli, T., K. Launonen \& M. Saarela 2005. Aura: yhteisön ja sen autistisen jäsenen vuorovaikutuksen ja viestinnän arviointiin ja kehittämiseen. Lahti: Avain-säätiö.

Ranta, M. 2011a. Taideterapia neuropsykologisessa kuntoutuksessa. Teoksessa M. LeijalaMarttila \& K. Huttula (toim.) Taidepsykoterapia: Psykonalayyttinen näkökulma. Helsinki: Duodecim, 451- 458.

Ranta, M. 2011b. Visuaalisen prosessoinnin neuropsykologiaa. Teoksessa M. Leijala-Marttila \& K. Huttula (toim.) Taidepsykoterapia: Psykonalayyttinen näkökulma. Helsinki: Duodecim, 57- 61.

Rose, G. 2001. Visual methodologies. An introduction to the interpretation of visual materials. London: Sage Publications.

Sarajuuri, J. 2008. INSURE-aivovammakuntoutusohjelma. Teemajulkaisu Taideterapia neurologisten potilaiden kuntoutuksessa. Taideterapia. Suomen Taideterapiayhdistyksen jäsenjulkaisu v. 2008, 6-9. 
Schütz, A. 2007. Sosiaalisen maailman merkityksekäs rakentuminen (suom. V. Pietilä). Tampere: Vastapaino. Alkuperäisteos 1932 Der sinnhafe Aufbau der sozialen Welt: Eine Einlaitung in die verstehende Soziologie.

Seppänen, J. 2005. Visuaalinen kulttuuri. Teoriaa ja metodeja mediakuvan tulkitsijalle. Tampere: Vastapaino.

Shrubsole, K., L. Worrall \& E. Power 2018. Closing the evidence-practice gaps in aphasia management: are we there yet? Where has a decade of implementation research taken us? A review and guide for clinicians. Aphasiology 32 (8), 970-995. https://doi.org/10.1080/02687038.2018.1510112

Silvo T. 2008. Kuva itsestä. Kuvataideterapia osana INSURE- aivovammakuntoutusohjelmaa Käpylän kuntoutuskeskuksessa. Teemajulkaisu Taideterapia neurologisten potilaiden kuntoutuksessa. Taideterapia. Suomen Taideterapiayhdistyksen jäsenjulkaisu v. 2008, 10-12.

von Tetzchner, S \& H. Martinsen 1999. Johdatus puhetta tukevaan ja korvaavaan kommunikointiin. Helsinki. Kehitysvammaliitto.

Wadeson, H. 2001. An eclectic approach to art therapy. Teoksessa J. Rubin (toim.) Approaches to art therapy. Theory and technique. New York and London: BrunnerRoutledge, 306-325.

Wilson, B. A., J. Mole \& T. Manly 2017. Rehabilitation of visual perceptual and visual spatial disorders in adults and children. Teoksessa B. A. Wilson, J. Winegardner, C. M. van Heutgen \& T. Ownsworth (toim) Neuropsychological rehabilitation. The international handbook. Abington: Routledge, 234-243. https://www.routledgehandbooks.com/doi/10.4324/9781315629537.

Wilson, L. 2001. Symbolism and art therapy. Teoksessa J. A. Rubin (toim.) Approaches to art therapy. Theory and technique. 2. edition. New York and London: Brunner- Routledge, 40-53. 